\title{
"TAKE A GOOD LOOK AT IT": SeEing Postcolonial Medianatures With KAREN TEI YAMASHITA
}

\author{
WALTER GORDON
}

“...We will require a vast store for culture to provide storage for the flood of incoming information. Otherwise we will suffocate from a surfeit of information rather than of waste."

- Vilém Flusser, Into the Universe of Technical Images

"Well, I am full of such coincidental information, and international at that! But, to continue..."

- Karen Tei Yamashita, Through the Arc of the Rain Forest

\section{Introduction-The Nature of Plastic}

Karen Tei Yamashita's 1990 novel Through the Arc of the Rain Forest tells the story of how a newfound substance, a special kind of plastic discovered underground, deep in the Amazon, comes to function both as an object and producer of culture, capital, and information. One of the novel's central characters, the three-armed American capitalist J.B. Tweep, also known as the "Assistant to Assistant Manager" of the Sisyphean "Development Resources Research and Viability" department at GGG Enterprises - a blank slate of a corporation he eventually comes to effectively run-makes it his mission to conduct "research concerning the nature of the Matacão's plastic," as it comes to be called, such that he is "constantly churning up new information" about the 
miraculous substance. ${ }^{1}$ That J.B. is interested in the "nature" of this speculative "plastic," is not a contradiction: the material seems to be the world's first "naturally" occurring plastic, forming, as we learn late in the novel, out of a combination of anthropogenic action - the massive accumulation of nonbiodegradable material on a global scale — and geologic forces, which force the trash into a new form under "tremendous pressure." 2 The image of J.B. "churning up new information" brings to mind both the never-ceasing, progressive yet cyclical form of corporate research, but also the elemental heft of the Matacão itself as an object of research, the physical resistance its materiality poses to its transformation into information. And while the hunt for information about the Matacão as a material drives much of the action of the novel, the substance's capacity to hold "information"-its capacity to act as media-emerges as perhaps its most revolutionary quality, of which J.B. is not unaware.

Taking the capability of the Matacão plastic to hold information as a starting point, this article will examine Through the Arc of the Rain Forest as a source of early insight into the collision of ecological, media theoretical, and postcolonial thinking that would not emerge as a serious focus within the academic world until more than a decade after the novel's publication. As a highly self-conscious and narratively rich work of fiction, the novel comes to function as a theoretical text that is able to sidestep existing disciplinary boundaries and thus provide a compelling picture of media ecology that places the necessity of interpreting ecological objects - which includes things like chunks of plastic - as media, thus placing questions of extraction, manufacture, and environmental change at the center of our understanding of modern media at the same time that it encourages us to rethink ecology itself as a form of mediation. In this introduction, I will briefly explore one important form of material media in Yamashita's text before turning, in the following sections, to the novel's academic antecedents and the particular way in which Through the Arc of the Rain Forest so distinctly anticipates the work of those more recent scholars.

One of the first uses of Matacão plastic that Yamashita introduces in her novel is, in effect, to make the mysterious geological substance into digital media:

\footnotetext{
${ }^{1}$ Karen Tei Yamashita, Through the Arc of the Rain Forest : A Novel (Saint Paul, MN: Coffee House Press, 1990), 141.

2 Ibid., 202.
} 
One of the great breakthroughs in plastics had to do with the magnetism of Matacão plastic. Not only did this open up new possibilities for refrigerator magnets, it was also discovered that this magnetism could be programmed in an infinite number of "addresses," making possible GGG's personalized credit cards without numbers or names. Matacão plastic magnetized credit cards were virtually indestructible and impossible to counterfeit. GGG, of course, would provide the computerized scanner to read the magnetized, coded information held within a seemingly blank piece of plastic. Instantly, a wealth of data regarding the purchaser...could be made available on a monitor. ${ }^{3}$

Programmed with "addresses" - in scare quotes in Yamashita's original, as if to signal the slippery digital metaphorics that can make a place out of a thingthe card quickly ceases to be plastic, as it is dematerialized into a media ecology. As the indestructible carriers of a seemingly infinite variety of information, the Matacão credit cards might represent the apotheosis of a technical object, one which seems to have transcended completely its status as a material thing and entered into the disembodied realm of digital media - what we might today call the cloud. J.B.'s "seemingly blank piece of plastic" produces such a high level of trust in its disembodied reliability that "people would be able to use [the cards] to purchase things like real estate, stock, and bullion;" the card, that is, "turned plastic into gold." material alchemy, J.B. projects that there should come a time when the magical plastic might dematerialize money altogether: "some even predicted," Yamashita writes, "that currency would cease to be used by the year 2020 or

\footnotetext{
${ }^{3}$ Ibid., 141.

${ }^{4}$ Yamashita, Through the Arc, 141. Barthes understands the ability to "turn plastic into gold," or at least the possibility of doing so, as the underlying fact of the mythology of the material: "more than a substance," Barthes writes, "plastic is the very idea of its infinite transformation... it is ubiquity made visible." Yamashita's novel in my view is a kind of riposte to Barthes' now-dated essay in Mythologies, which posits plastic as the product of "raw, telluric matter," which becomes "the finished, human object" by a process that is essentially "nothing; nothing but a transit, hardly watched over by an attendant in a cloth cap, half-god, half robot" (Barthes 97). In Through the Arc of the Rain Forest - and perhaps in the current moment of ecological crisis conceived broadly - there is no longer "raw, telluric matter" that one can point to, and there is certainly more to the process of the making-usable of Matacão plastic than "nothing but a transit."
} 
even sooner." An all "MCC" global economy, J.B. assures us, is a "real possibility," a future contingent only on advances in security and technology. ${ }^{6}$

This vision of an immaterial future promised by a miracle material is, of course, a myth — or perhaps a dream: the chapter in which the cards are introduced begins as a sales pitch by J.B. to Kazumasa Ishimaru, another of the novel's central characters, for whom another bodily oddity - a ball of Matacão plastic, the narrator of the novel, that floats in front of his head-establishes him as a vital figure for J.B.'s image of a plastic future. Although the conditional tense of the passage eventually drops out - and, in later, chapters, the dissolution of Matacão plastic items makes it clear that they were, indeed, real-it never becomes entirely clear in this chapter whether the plastic inventions are things in the world, or in J.B.'s head. "The new technology associated with the Matacão plastic," Yamashita writes, "would rapidly become the wave of the future, and GGG Enterprises was definitely leading this wave with most of the technology under wraps...GGG would revolutionize the plastic market with one incredible novelty after another. ${ }^{7}$ As J.B. slides in this reported speech from the conditional tense of a salesperson ("would rapidly become") to the assured repetition of characterizing the credit card as the foremost in a series of "incredible novelties," coming one "after another," J.B. gestures towards the logic of planned obsolescence, the cyclical design strategy that still dominates our material relations to digital culture today, filling our landfills with complex and often toxic forms of mineral and plastic waste. Electronic waste (e-waste), according to Richard Maxwell and Toby Miller's Greening the Media, is "mostly produced in the Global North," and mostly "dumped in the Global South," much, I think, to no one's surprise. ${ }^{8}$ In Yamashita's unique speculative media ecology, however, the Matacão products are not only set to once again one day become waste in the global south, but

\footnotetext{
${ }^{5}$ Ibid., 142.

${ }^{6}$ J.B.'s dream of an immaterial future for money is reflective of a larger narrative of the dematerialization of money in modernity, which has only accelerated given the late capitalist confluence of digital technology and global finance. As Bill Maurer writes, "in scholarly and popular venues, the story of money is repeatedly told as an evolutionary tale of greater and greater distance from actual things, of greater dematerialization, in a linear trajectory from barter, to metal coin, to paper backed by metal, to paper declared valuable by fiat, and, finally, to complex financial entities like derivatives, with future, not anterior, backing" (Maurer 140). The extreme usefulness of Matacão plastic — and its attendant material value - would seem to buck against this trajectory even as J.B. imagines it aiding in its continuity: the high value of Matacão plastic itself would appear to disqualify it as a modern medium of exchange.

${ }^{7}$ Ibid., 141, emphasis mine.

${ }^{8}$ Richard Maxwell and Toby Miller, Greening the Media (New York: Oxford University Press, 2012), 3 .
} 
they also come from waste collated in that same space. When waste passes through the arc of the rainbow and becomes its opposite, as Yamashita writes in the novel's epigraph, it becomes media; then, in the rainforest, where "the rain never ceases and the rainbows are myriad," it becomes waste again. ${ }^{9}$ As a result of the modern global distribution of capital and development, a discernable geography of electronic waste has developed alongside — or from within-Fanon's geography of hunger. ${ }^{10}$

I invoke Fanon here because I want to insist that Yamashita's novel pushes the reader to think about questions of media and ecology alongside the history and legacy of colonialism and neoliberalism. By deploying the logic of planned obsolescence and raising the spectre of electronic waste, J.B. discloses the central way in which the immateriality of the credit card is a dream: as a piece of transformed Matacão plastic, it is both the product and the future promise of material waste, to be collected from and ultimately deposited in the global south. It is only a "seemingly blank piece of plastic"; there is nothing "blank" about the history of its extraction, nor is there anything contentless about its material fate. Despite his desire for the plastic card to dissolve into the immateriality of international finance capital, its status as the product of mental "churning," as well as actual "cutting," "molding," and "shaping," keeps the Matacão firmly tied to the material world of geology, ecology, and extraction. The special properties of Matacão plastic as a material both make the credit card possible, and open the possibility of the forgetting of its materiality - and more specifically, the forgetting of its material cost. This cost, as the remainder of the novel shows, is significant, and, while it is initially incurred in the depths of a rainforest in an underdeveloped nation, the particular arrangement of neoliberal geopolitics in which the novel is situated ensure that the local problem of media extraction becomes global in spatial terms, and profoundly extensive in temporal ones. Moreover, by inventing a substance formed through an accelerated version of the geological processes that contribute to the formation of oil but which is, importantly, built out of anthropogenic raw material rather than prehistoric, Yamashita produces an oblique theory of oil as a medium that never loses sight of the way humans are interpolated into their media environments as much as the natural one. As "probably the most celebrated" of petroleum products for its "contribution to easy modern living," plastic, like software, as Carolyn Elerding has argued, both "exemplifies and

\footnotetext{
${ }^{9}$ Yamashita, Through the Arc, n.p.

${ }^{10}$ Frantz Fanon, The Wretched of the Earth, trans. Constance Farrington (New York: Grove, 2002 [1961]), 96.
} 
obscures petroculture... as the basis of digital culture". ${ }^{11}$ In other words, plastic not only allows us to produce and make use of the various forms of digital media that constitute "easy modern living," it also acts as a key force mediating our relationship to the material basis of that lifestyle: oil.

This article will track one way in which that obfuscation has taken place in relation to plastic, even — or perhaps particularly-within the discursive space of academia. In the following third of the article, I will contextualize Yamashita's plastic vision of the ecology of a neoliberal media culture by giving a brief history of the recent disciplinary convergences of media studies, ecocriticism, and postcolonialism, showing the valuable methods each bring to the others, ending with a brief case study of disciplinary non-arrival that attests to the necessity of thinking the three together. I will then turn back to Yamashita's novel and close read a brief section as a promising, proleptic picture of the intersection of the three, which hinges on the author's careful attention to the extended "lifecycle" of the various forms of media that populate her text: just as J.B. and Kazumasa bear witness to the "birth" of media out of the uneven, global environment, Yamashita represents its "death" as well, and the stark, temporally disruptive ecological consequences thereof. I will conclude, finally, by offering a reading of the novel's mysterious narrator, whom it is fruitful to understand, I will argue, as a kind of digital media, not unlike J.B.'s credit card, in order to reflect on the limits of the media concept, and its relationship to syncretic cultural forms and the blinders of secularism.

\section{Disciplinary (Non)Convergence: The Problem of Postcolonial Medianatures}

Though a certain amount of ecologically engaged media studies has emerged over the past decade, the delayed convergence of the two fields is worth investigating. Many works of media studies since mid century have taken the work of Marshall McLuhan as a historical touchstone - with varying degrees of disavowal - and the distance between media and actual ecology can, I think, be traced to this critical heritage. John Durham Peters' note in his ecologicallyminded The Marvelous Clouds (2015) about the 50 th anniversary of Understanding Media (1964) is representative of the general attitude towards McLuhan in contemporary media studies: "McLuhan helped invent media

${ }^{11}$ Matt Huber, Lifeblood: Oil, Freedom, and the Forces of Capital (Minneapolis, MN: University of Minnesota Press, 2013), 84; Carolyn Elerding, "The Materiality of the Digital: Petro-Enlightenment and the Aesthetics of Invisibility," Postmodern Culture 26, no. 2 (2016): $1-2$. 
studies in the spirit in which I pursue it, though the field both deserves a wider lineage... his brilliance covers a multitude of sins." 12 Later, Peters adds in parentheses a kind of method for reading McLuhan now: "(For that matter, many of McLuhan's claims don't hold up today, perhaps mostly because they didn't hold up in 1964. One reads McLuhan for sparks, not scholarship)."13 While the kind of hostility that many media theorists and historians direct towards McLuhan has certainly made room for productively critical readings and "sparks," many of his claims - among them, importantly for me, those that distanced, perhaps unintentionally, the study of media from the study of the natural world - still haunt media studies today. Nature was above all for McLuhan a metaphor, or a rhetorical device, through which he could make his ideas about the legibility of media more legible: nature functions as a "medium," in the broadest sense for McLuhan-it is a (linguistic) thing through which another thing is communicated - but he did not consider it as such. When McLuhan writes, "TV is environmental and imperceptible, like all environments," he is translating, in essence, his sloganized "medium is the message" into arbitrarily "ecological" terms, not offering an interpretation of television as a medium as related to literal environmental structures. ${ }^{14}$

So the damage was done: as Maxwell and Miller note, "by the 1970s, the idea had taken hold that media analysis was 'resolved with a metaphor' of environments," and, on the publication of their Greening the Media in 2012, the authors were still able to assert that "the substitution by the metaphorical still obscures the ecological context of media technology," such that their monograph had "no tradition of ecological history to draw on." ${ }^{15}$ Media studies, in other words, (forgivably) stumbled out of the gate in how it situated itself in relation to the natural world and to the academic disciplines that make that world its object of study: media ecology has been and still is mostly a metaphor. And, as Ursula K. Heise notes in her bluntly titled "Unnatural Ecologies: The Metaphor of the Environment in Media Theory," it isn't even a particularly good metaphor, or at least not a very precise one; "Envisioning media as an environment," Heise writes, "leads different theorists to radically divergent conclusions," reading "technology as an all-encompassing system or,

\footnotetext{
12 John Durham Peters, The Marvelous Clouds: Toward A Philosophy Of Elemental Media (Chicago: University of Chicago Press, 2015), 15.

13 Ibid., 17.

${ }^{14}$ Marshall McLuhan quoted in Maxwell and Miller, 14.

${ }^{15}$ Maxwell and Miller, 14.
} 
in contrast, as an image that counteracts this kind of system." "16 Though it comes more than ten years after Heise's call for "the 'greening' of media ecology," Maxwell and Miller's monograph makes significant strides towards correcting this omission, and their expansion of "the life of electronic objects," to encompass both the raw materials from which media are formed and the eventual material fate to which they succumb is valuable for thinking about the kind of media-entangled natures to which Yamashita gives novelistic form. ${ }^{17}$ Indeed, when Yamishata's Mané Pena, a formerly poor forest dweller who becomes an international star and "feather guru" - a kind of salesman, televangelist, and public intellectual all in one - is trying to soothe another character, heartbroken at the recent absence of his wife, Yamashita has her guru reverse McLuhan's pseudo-environmental formulation, as if to point both to its usefulness and its essential misguidedness: "Nature's like the TV," he says, "you take a good look at it; it'll tell you something new all the time." 18 Taking "a good look" at a TV, Maxwell, Miller, and other ecologically oriented media theorists would assert, literalizing Mané's metaphor, can actually tell us "something new" about nature, and our relations to it, just as looking at nature can tell us "something new" about media and its materiality.

One earlier theorist of media who did see nature when he took a close look at his object of study is Vilém Flusser, whose idiosyncratic work belongs to the "wider lineage" of media studies that Peters gestured to in the sentence quoted above, a lineage from which nature is, indeed, not nearly as absent as it is from the work of McLuhan and his "media ecological" descendants. ${ }^{19}$ Flusser was born in Prague but was forced to emigrate at the outbreak of the Second World War, and spent the vast majority of his working life in Brazil, between São Paolo and Rio de Janeiro. His 1985 Into the Universe of Technical Images tracks the emergence of digital media, and projects the coming of a "telematic" society which will "render superfluous" not only other

\footnotetext{
${ }^{16}$ Ursula K. Heise, "Unnatural Ecologies: The Metaphor of the Environment in Media Theory," Configurations 10, no. 1 (2003): 161.

${ }^{17}$ Heise "Unnatural Ecologies," 168; Maxwell and Miller, 20.

18 Yamashita, Through the Arc, 116.

19 The "Media Ecology Association," whose Mount Rushmore-like banner on their website not coincidentally features ten white Americans and European intellectuals, for instance, describes its work as examining how "technology and techniques, modes of information and codes of communication play a leading role in human affairs," while any mention of "nature" or actual ecology is absent from their language ("What is Media Ecology?", qtd. in Maxwell and Miller, 169n42). By restricting the media ecological to the thin slice of the "life of electronic objects" in which they function straightforwardly as "codes of communication"-rather than as, for instance, toxic trash_-produces a distinctly non-environmental image of media environments.
} 
conventional media like "newspapers, books, [and] letters," but also "businesses, offices, factories, theaters, cinemas, concert halls...exhibitions," and, lastly_like the MCC_- "money". ${ }^{20}$ While Flusser's telematic society might appear to be the worst kind of gadgety utopia that earlier media theorists are often taken to task for naively imagining, his interest in the way that the drive towards telematics can be understood as a drive towards the permanent storage of information - a drive towards infinite memory, an idea that is key to Yamashita's novel — comes in a uniquely ecological form. Media has always been oriented towards combatting the decay of information, Flusser writes,

But it was always a lost cause, for all storage media, because they are material, which is to say natural, are subject to the second law of thermodynamics and must decay along with the information they carry...All information must decay if it is stored in a material medium. Once this is accepted, all linear models of history must be abandoned. History is then no longer a linear process of human beings transforming nature into culture. The situation is rather this: human beings progressively tear things from nature to impress information into them, that is, to turn them into cultural objects. ${ }^{21}$

By noting that "storage media, because they are material," must therefore be grasped as "natural," Flusser is inaugurating precisely the kind of properly ecological media theory that Yamashita will pick up less than a decade later in her novel. As Yamashita makes clear with the Matacão credit card, paying attention to the processes through which we "tear things from nature," in order to make them into usable media is necessary in order to imagine media studies under global capital. What's more, since "information must decay if it is stored in a material medium" - which is to say, a natural medium - it must eventually return to nature: "we are looking at a cycle of nature-culture-waste-nature," Flusser writes, such that the development of media technologies becomes a process of attempting to halt that cycle, or at least slow it down, to extend the period in which media belong to "culture."22 "But perversely," Flusser continues, attempting to halt the cycle — by using "plastic bottles instead of glass ones," for instance - tends instead to "halt the degenerative cycle not at the point of remembering but at the point of waste, of forgetting. The plastic bottle is discarded just as quickly as the glass one but lasts longer before

${ }^{20}$ Vilém Flusser, Into the Universe of Technical Images (Minneapolis, MN: University of Minnesota Press, 2011 [1985]), 82.

${ }^{21}$ Ibid., 108.

${ }^{22}$ Ibid. 
returning to nature." 23 While the idea of a plastic bottle "returning to nature" seems to evince a certain misunderstanding about the nature of synthetic polymers and biodegradation, the idea of a "nature-culture-waste-nature" cycle of media life maps propitiously onto the postcolonial medianature of Through the Arc of the Rain Forest, in which, far from coming to a halt on "culture" or "waste," a kind of plastic-induced temporal collapse disrupts the cycle, such that "culture" constantly leaks into "nature" and "waste" and vice-versa. This "ontological flicker," to borrow a phrase from Brian McHale, is what happens when one looks closely at media with an ecological eye: one sees trash and nature where one once saw media; one sees media and trash where one once saw nature. ${ }^{24}$ To make explicit the contradiction I see between my epigraphs, what Yamashita's trashy narrator observes, contra — or by extension ofFlusser, is that waste in fact stores information.

Jussi Parikka's concept of "medianature" provides us with a useful shorthand for naming the nature-culture-waste-nature cycle that Flusser identifies. In his most recent monograph, $A$ Geology of Media, Parikka positions nature, especially geophysical nature, as something that "affords and bears the weight of media culture, from metals and minerals to its waste load." 25 Derived from Donna Haraway's "natureculture," Parikka's medianature names the "double bind" of the relationship between media and nature: at the same time that the natural world "becomes registered through the ordering of media reality," the "affordances of geophysical reality"-like the magnetism of Matacão plastic_- "make technical media happen." ${ }^{26}$ In other words, media and nature are co-constitutive: media makes nature; nature makes media. Allowing for the double bind of medianatures lets Parikka think, as Maxwell and Miller do, about how the "materiality of media starts much before media become media," and, in a parallel fashion, how one might extend media theoretical critique to "discuss the media that are not anymore media." 27

My intervention, by way of Yamashita, is to insist that the double bind of medianatures be understood in the context of the legacies of colonialism: the coloniality of medianatures, to adapt Arturo Escobar's term, has thus far gone

23 Ibid., 109.

24 Brian McHale, "Real, Compared to What?" in Postmodernist Fiction (New York: Methuen, 1987), 90.

${ }^{25}$ Jussi Parikka, A Geology of Media (Minneapolis, MN: University of Minnesota Press, 2015), vii.

26 Ibid., 13.

27 Ibid., 37. 
largely unregistered. ${ }^{28}$ One of the earliest explicit attempts to bring together postcolonial thought and media studies, Maria Fernández's 1999 essay "Postcolonial Media Theory," predates the convergence of media studies and ecocriticism (as well as that between ecocriticism and postcolonial theory), but the combination wasn't picked up for nearly a decade, in Brian Larkin's Signal and Noise (2008), and, much later, Kai Merten and Lucia Krämer's edited collection Postcolonial Studies Meets Media Studies (2016), and Raka Shome's "When Postcolonial Studies Meets Media Studies" (2016). Fernández's essay provides a wide ranging survey of postcolonial studies and media theory, which locates points of convergence in a shared "preoccupation with the body, identity, history, feminism, and agency"; even if the two disciplines have radically different takes on these select topos, the shared conceptual ground would seem to lend itself, Fernández rightly observes, to being "used imaginatively toward common ends." 29 Why, then, didn't "postcolonial media theory" emerge with Fernández? The failure of the two disciplines to respond to Fernández's call for a synthesis comes in part from her insubstantial and slightly dishonest portrayal of media studies, which she imagines as a monolithic disciplinary structure that is "knowingly or unknowingly doing public relations work for digital corporations" by theorizing "electronic technologies...as either value-free or inherently liberatory." 30 While this may be true of some theorists, many - including most I have discussed in this essay so far-would balk at that description, and disavow precisely the same "fantasies of disembodiment and autonomy," that Fernández does, to borrow a phrase from Cary Wolfe's gloss on the kind of naively celebratory posthumanism of figures like Hans Moravec, whom Fernández cites as

${ }^{28}$ Parikka's 2011 introduction to his edited electronic monograph Medianatures: The Materiality of Information Technology and Electronic Waste, does actually do the work of thinking about the intersection with postcolonial theory: "the mineral allows us to consume mediatic content but has at the same time its own genealogies of matter and politics," he writes, "for instance in bloody wars in the Democratic Republic of Congo, where a range of European mining companies have had their own dubious part to play, including funding the war efforts in order to secure the extraction of the mineral" (Parikka, 2011, n.p.). Why this drops out as a point of emphasis in his later text is not entirely clear, but I imagine it has to do with the case studies he chooses in A Geology of Media, which tend towards European and American works of art. It also might come from his tendency in the monograph towards new materialists like Jane Bennett, and object-oriented ontologists like Ian Bogost and Eugene Hacker, who, in John Durham Peter's words, are occasionally "so ambitious in celebrating quirky lists of things in all their varied wonder" such that "the sometimes brutally hierarchical and unequal character of things disappears from view" (Peters, 29-30).

${ }^{29}$ Maria Fernández, "Postcolonial Media Theory," Art Journal 58, no. 3 (1999): 60.

${ }^{30}$ Ibid., 59. 
representative. ${ }^{31}$ Indeed, Fernández's essay as a whole gives the feeling that she is less interested in finding a new methodology by way of synthesizing aspects of postcolonial theory and media studies than she is in seeing the political and philosophical whipping into shape of the former by the latter.

Above all, however, what Fernández essay lacks - through no fault of her own - is the ecocritical arrival in media studies that I have described above: without the environment it is exceedingly difficult for Fernández to see colonialism in relation to media, as her only point of entry is "the incorporation into the global market of parts of the world" that can only recently "afford connectivity"; she can only see, in other words, "living" media. ${ }^{32}$ But, as I have already shown, from the moment the global south became imbricated in the trade of raw materials necessary for "the life of the digital object," "connectivity" had already arrived. Without the archive of ecocritical media studies, Fernández could not form an argument like Shome's when she, with a nod to Maxwell and Miller, calls for "new technological developments not just through a logic of 'innovation' but also destruction, since most companies (e.g. Apple) manufacturing such smart products sell the 'innovation' logic to the consumer when a product is launched but rarely allow the consumer a glimpse of the destruction of vulnerable populations that occurs when the 'innovative' product ceases to be cutting edge and is discarded and shipped away as e-waste to the margins of globality." 33 Without the ability to think in "green" terms about media, it becomes much more likely that "millions of people in various parts of the non-Western world fall out of the history of media (and its functioning and assumptions) that we narrate in the west," producing "a history that advances a view of modernity that is locked in the temporal logics of North Atlantic modernity." 34 Yet as Yamashita's novel dramatizes, and as she literalizes in a speculative geology of globally flowing plastic, residents of Brazil and other underdeveloped nations didn't have to wait for the arrival of "digital culture" per se before they began to feel its effects. In what follows, I would like to turn back to Yamashita's novel to show how her descriptions of the environmental impact of the Matacão and its transformation into media, or as the narrator calls it "a stage for life and death," register the presence of the

${ }^{31}$ Cary Wolfe, "Introduction: What Is Posthumanism," in What Is Posthumanism? (Minneapolis, MN: University of Minnesota Press, 2010), xv.

${ }^{32}$ Fernández, 60.

${ }^{33}$ Raka Shome, "When Postcolonial Studies Meets Media Studies," Critical Studies in Media Communication 33, no. 3 (2016): 255. Shome recognizes Fernández's earlier contribution and notes that "not much has changed since her critique," but doesn't make the connection between Fernández's failure to launch and her lack of access to ecocritical thought.

34 Shome, 246. 
global south in the history of media, enabling a theoretical approach that pushes back against the classical stadial view of the history of modernity that Shome rightly identifies as the byproduct of a more limited image of media.

\section{Dying Media in Deep Time: Runoff and The Future}

The first real sign that transforming the Matacão into media might have detrimental environmental effects comes in a passage that describes the movement of information of the danger from research, to interpretation, to corporate spin and rhetorical appropriation:

Then, there was the growing concern over the mining process of Matacão plastic. The chemical runoff from GGG's secret technique had been collected and analyzed and found to cause genetic mutations in rats after five generations. The mutations were most bizarre and grotesque. Rats were found to develop fangs and tiny horns and an eager appetite for blood. The idea of vampire rats caused a shudder of horror and speculation about a tropical Transylvania. However, some later generations were found to sport extra appendages - research that J.B. followed with particular interest. Such aberrations of the general mutation process caused by Matacão mining runoff gave J.B. reason to justify the pollutant. The GGG official write-ups stated, "GGG Enterprises has a firm policy of environmental concern. All runoff from Matacão mining is collected, encapsulated in stainless-steel containers and sealed at strategic disposal locations. GGG's disposal locations will not impact the social or environmental structure as they are usually spaces made vacant by the mining itself. Sophisticated collection procedures guarantee a 98.2 percent collection of runoff material. Additionally, research and development is proceeding to find methods to extract and employ the currently known benefits from runoff." 35

In this important paragraph, Yamashita details the way that knowledge about media and the environment moves itself through an uneven media ecology, producing new forms of life, time, and government. In the context of the previous paragraph, which details the environmentalist reaction to the "rape of Mother Nature" that has resulted from the distribution of feathers, another

\footnotetext{
${ }^{35}$ Yamashita, Through the Arc, 160-61.
} 
GGG "product," we know that the oddly passive phrase "there was the growing concern" must be referring to the same group of environmental activists. ${ }^{36}$ These activists, we might infer from earlier in the book, do not live in the area of the Matacão - and therefore will not, presumably, be affected by the runoff-but instead belong to "international ecological groups" whose main concern is with the destruction of the "enormously photogenic" Amazon forest, which makes for "beautiful calendars." 37 But now, with the extraction of the plastic, their interest is given less to "the area around the Matacão" in the sense of an image of pristine jungle than it is on that same area which is now subject to "chemical runoff." 38 Somebody - it is unclear who-conducts research on the runoff, using rats, and, on finding the possibility of mutation, sounds the public alarm, causing - again in an oddly passive way - "a shudder of horror and speculation about a tropical Transylvania." 39 In this science fictional tale, the only way that the public knows how to react to the reality of mutation and toxicity is through recourse to the similarly generic: despite the existence of real animals in the world that have "eager appetites for blood"-like the mosquito, for instance, whose role in the spread of Yellow Fever and other diseases has played a significant role in the history of Brazil - the possibility of the emergence of "vampirism" takes hold. ${ }^{40}$ Already, the knowledge of an environmental problem has been transformed via the literary imagination into a "panic" for which there is no solution, except, we might imagine, something equally fantastical: the more "bizarre and grotesque," the environmental problem, the farther outside of the everyday imaginary one must look for resolutions.

J.B., too, of course, catches wind of the research, and takes a special interest in the "later generations" of rats who were found to "sport extra appendages." 41 This is an important moment for my reading of the Matacão as a kind of medium because, although Tweep does not understand his own extra arm as the product of plastic-induced mutation, the possibility of a link between his third arm and the Matacão_-like the link between Kazumasa's ball and the plastic mantle, as I will discuss in my conclusion-begins to open up

\footnotetext{
${ }^{36}$ Ibid., 159-60.

37 Ibid., 98.

38 Ibid., 160.

39 Ibid.

${ }^{40}$ See J.R. McNeil, Mosquito Empires: Ecology and War in the Greater Caribbean, 1620-1914 (Cambridge, UK: Cambridge University Press, 2010) for a provocative account of the role of the Mosquito in the history of the Greater Caribbean, especially pp. 91-97 on Brazil.

41 Yamashita, Through the Arc, 160.
} 
the site of the bodily person for inclusion in a properly "green" media ecology. When the reader is first introduced to J.B.'s third arm, we learn that he conceives of it, in a sense, as media, as "he accepted his third arm as another might accept ESP, an addition of 128k to their random access or the invention of the wheel." 42 Just as the Matacão credit card that can be programmed with addresses, J.B. comprehends his third arm at once as something like a technical object (the wheel), a communicative process (ESP), and an information storage device (a bearer of random access memory). Further, J.B.'s self-image as a "better model, the wave of the future," again places him within the logic of planned obsolescence and disposal that characterizes the global sphere of medianature. ${ }^{43}$ J.B. is less a Social Darwinist than a believer in the kind of entrepreneurial posthumanism that Fernández and Wolfe both despise, whose eye is set firmly on the proliferation of "better models" into "the future." 44 The runoff, in J.B.'s hands, thus becomes something with "known benefits," which he must then find a way to cultivate.

To do so - and to preserve the image of "environmentalism," J.B. must first store it in "stainless-steel containers" which are "sealed at strategic disposal locations" that "will not impact the social or environmental structure as they are usually spaces made vacant by the mining itself." 45 These spaces, of course, precisely because they have been "made vacant by the mining themselves" have already felt an "impact" on their "social or environmental structure" - to mine Matacão is to "impact" environmental structure; to transform it into media is to "impact" the social. But "sophisticated collection procedures," J.B. insists in the "official write-up," will "guarantee a 98.2

42 Ibid., 30.

${ }^{43}$ J.B.'s self-positioning as a "better model" also brings to mind the reason for Kazumasa's presence in Brazil in the first place: he was forced to leave Japan, essentially, because his usefulness as a railroad inspector was superseded by the development of a cheaper, "digital" version of himself, with a "five-year parts warranty and a renewable repair policy" to boot (8). In Brazil, which, "unlike Japan... was massive, inefficient, encumbered by bureaucracy, graft and poverty," Kazumasa is able to persist in usefulness as a "dated" technological object, much as "trashed" media becomes media again once it is exported from the north to the global south (10).

Mané Pena and his circle, too, register the oddly medial nature of J.B.'s third arm, when the narrator describes their reaction to it as "a sort of quiet awe, rather like, Mané thought, seeing television for the first time" (74). The constant comparisons of J.B.'s arm to different forms of media recalls one of McLuhan's early definitions of media as a kind of prosthesis, as an extension of the self - only in J.B. it is "naturalized," as Yamashita's highly literal medianature pervades even her characters bodies.

${ }^{44}$ Yamashita Through the Arc, 160.

${ }^{45}$ Ibid. 
percent collection" rate, so that the placement of the stainless steel tanks should, in theory, matter a great deal. As Ulrich Beck points out in Risk Society, however, the rhetoric of "98.2 percent" does much to produce "the absence of any social differentiations" in risk reporting: "a person who inquires about the average," - or a person who reports an average, like J.B.-_"already excludes many socially unequal risk positions." 46 The figure of "98.2 percent," like the sly "usually" which he attaches to the geographical description of the runoff containers, "only reflects the general state of scientific and social thought with regard to environmental problems." 47 Through "the loss of social thinking," in Beck's words, J.B. is able to elide the actual material effect of collecting runoff, while appearing to dedicate himself fully to counteracting it.

The "stainless-steel containers" also bring to mind one of the real life analogies that is helpful for thinking through the Matacão and its impact: the technological, material forms of "environmental stewardship" that emerged to deal with the question of nuclear fallout in the twentieth century. Although the Matacão and its impact is never directly likened to nuclear toxicity, the amount of capital that is imported from the United States (only possible because of "Brazil's debtor-nation IMF agreements," the narrator reminds us) to fund another of GGG's efforts - the mass distribution of the feather-is directly compared to the funds brought in to build "Angra dos Reis, a nuclear-powered reactor that never worked." 48 More directly, a "Live Aid" event is held on the Matacão "to raise money for victims of nuclear fallout in Nevada, Utah and Arizona," where, as Joseph Masco notes, the "subtle but total transformation of the biosphere" by way of nuclear toxicity was first made into a "normalized (all but invisible) aspect of daily life." ${ }^{49}$ With the Matacão, a "stage for life and death," Yamashita finds a way to link two massive environmental problemsnuclear toxicity and the life cycles of media - one of which is far more visible and easier to communicate than the other: there is no need to liken "victims of nuclear fallout" to vampires, one can simply understand them as victims.

Finally, the encapsulation of Matacão runoff brings the problem of media ecology into a different temporal register, one that is more appropriate for imagining a truly postcolonial medianature. Just as the extension of media

${ }^{46}$ Ulrich Beck, Risk Society: Towards a New Modernity (Newbury Park, CA: Sage Publications, 1992 [1986]), 25.

${ }^{47}$ Ibid.

${ }^{48}$ Yamashita, Through the Arc, 75-76.

${ }^{49}$ Joseph Masco, "Mutant Ecologies: Radioactive Life in Post-Cold War New Mexico," in Global Political Ecology, eds. Richard Peet, Paul Robbins, and Michael Watts (London \& New York: Routledge, 2011), 287. 
studies to encompass the "deep time" of geology "before media become media" lets us read the Matacão as part of a singular medianature, the invocation of sealed runoff containers points to the deep sense of futurity that becomes necessary once we understand that media might one day become an unwieldy mass of toxic trash. ${ }^{50}$ The image of "stainless-steel containers" dotting "GGG's disposal locations" forces us to think media studies beyond "the temporal logics of North Atlantic modernity" and into what Masco calls the temporality of "long-term stewardship," in which "the logic of national security is inverted; the threat of foreign arsenals and armies are replaced by an internal discourse of contamination and territorial colonization." ${ }^{51}$ Masco's analysis is of a kind of self inflicted ecological wound - the U.S. American project of long-term stewardship developed in response to the internal experimentation with nuclear devices (although, of course, that toxicity spread across borders ) - while the fallout of Yamashita's postcolonial medianature, however, is in a profound sense both internal and external: while the Matacão ended up in the rainforest because of a mixture of anthropogenic and properly "natural" forces, its transformation into media is fully the result of the international efforts of an American company literally transported to Brazil. Not only does the globalization of limited notions in North Atlantic modern media history "suppress other histories of media's functioning in other parts of the world," it also actively, Yamashita's novel shows us, elides the way in which it forces the invention and imposition of new temporal forms like the "deep future" of long-term stewardship, and the attendant "new form[s] of governmentality" that come with them. ${ }^{52}$ For J.B., the deep future is an opportunity, a chance to begin again the cycle of "research and development" — or perhaps that of nature-media-trash-nature — so that he might "extract" from the runoff in the same way that he did from the Matacão. For the narrator, however, the deep future represents another kind of futurity, one that depends less on a cycle of research and extraction than a recursive one of memory and forgetting. Just as Tweep's obsession with the Matacão and its temporal characteristics allows Yamashita to extend the lifecycle of the media concept into an ecological future, the narrator's transformation in that future time from plastic into spirit points to the limits of thinking through media in purely secular terms.

\footnotetext{
${ }^{50}$ Parikka, Geology, 5, 37.

51 Shome, 255; Masco, 297.

52 Shome, 246; Masco, 291, 297.
} 


\section{An Afterlife: Memory, Narration, and the Secularism of Media}

About halfway through the novel, when enough characters have collected in the rainforest and the narrator finally feels it is "appropriate to stop for a moment and discuss" the Matacão and its "dis-covering," it prefaces its answer to the puzzle of the Matacão's makeup by positioning it as an object that represents an epistemological break, a thing that "changes everything": "Nowadays, scientists cannot present papers or new findings without having to answer the now-common retort, 'But what bearing does the Matacão have on your findings? Or "How do you reconcile your hypothesis with the Matacão?" 53 Beyond providing a model of what I imagine it is like to work in a hard scientific discipline - or even how it feels to work, sometimes, in literary studies - after the arrival of the reflexive Anthropocene, this moment is a kind of challenge to readers and critics of the novel to attempt to account for one of its biggest questions: the narrator. ${ }^{54}$ The narrator is, after all, a ball of Matacão plastic; it might as well be asking: "but what bearing do $I$ have on your findings about my novel?" or "how do you reconcile your hypothesis with my presence?" How, then, do I think the narrator of the novel affects my hypothesis about Yamashita's speculative medianature? How does the narratoras-Matacão - who dissolves along with all of the other Matacão plastic towards the end of the novel—affect my conjectures of the "deep future" of postcolonial medianatures? ${ }^{55}$ The only way to effectively answer this, I think,

\footnotetext{
${ }^{53}$ Yamashita, Through the Arc, 95. I am aware of the readerly confusion that might result from the use of "it" to refer to the narrator, but I don't see a way around it that would not necessitate the compulsive repetition of the phrase "the narrator." I would also posit that the most likely of potential confusions caused by the use of "it" in the above sentence- the conflation of the narrator and "the Matacão" - is actually, in a sense, appropriate and accurate.

54 The Anthropocene is a term that has thus far floated somewhere behind or beneath this article, but which remains a vital conceptual tool for me, even if unspoken. I borrow the idea of a "reflexive" Anthropocene from Tobias Boes and Kate Marshall, who use it to mark the moment at which "the production of media technologies that facilitate the viewing of their own participation in geological change" becomes a possibility (Boes and Marshall, 65). I find this slight shift quite helpful in that it lets one hold on to the Anthropocene as a concept and a tool without getting caught up in debates about when it began.

55 Though the eventual absolute dissolution of the Matacão falls outside of the scope of this article-I thought that the moment of the discovery of "runoff" provided a richer web of ecological connections as an instance of the "death" of media-I would like to point to Yamashita's choice to have "bacteria" dissolve the plastic as yet another moment of intense prescience on her part: a recent paper in Science has reported the discovery of bacteria that is able to dissolve PET, one of the most common forms of plastic, and use it as "its major energy and carbon source" (Yoshida et al., 1196, qtd. in Taffel 371n4).
} 
is to think about the ball as Matacão on my own terms, and to consider it as a kind of a technical medium.

Previous critics have come close to this interpretation, but have maintained a certain distance through recourse to simile: as Molly Wallace observes, the ball "operates like a communications satellite for the reader, flipping between characters like channels on a television." 56 Heise takes a similar stance, while foregrounding the ball's relationship to the Matacão in the same way that I would like to: the narrator, writes Heise, "functions rather obviously as a miniature replica of the Earth itself, the voice that emerges from the depths of geology." 57 In accordance with my reading of the Matacão as representative of one stage in the life of media - its deep geological history-I would like to posit a kind of combination of Heise and Wallace's readings, by understanding it not as "like" a communications satellite but literally one, which speaks with the "voice that emerges from the depths of geology" in the same way that an actual satellite does, given their capabilities, as they are, by a combination of rare earth metals and durable plastics. What's more, that the Matacão is "plastic" and is able to "speak" dovetails nicely with Sy Taffel's recent observations that "the development of modern plastic and audiovisual material cannot be understood in isolation from one another," but instead "form a dyadic relationship" with technological developments in one feeding consistently into the developments of the other. ${ }^{58}$ The history of media technology in the $20^{\text {th }}$ century - though we might associate it more with the advent of the digital age and the rise of rare earth metals - is inseparable from the history of plastic.

Most important, however, is the link between Matacão plastic and programmable "memory": "by a strange quirk of fate," the novel begins, "I was brought back by a memory... I have become a memory, and as such, I am commissioned to become for you a memory." 59 What the narrator is describing here is precisely the "memory" theory of media that Flusser provides us with: information media are, above all, designed to preserve and extend memory, but they must necessarily degrade, and therefore must be able to transfer their memory somehow from medium to medium. The story of the novel, even if it

${ }^{56}$ Molly Wallace, “'A Bizarre Ecology' The Nature of Denatured Nature,” ISLE: Interdisciplinary Studies in Literature and Environment 7, no. 2 (2000): 149, emphasis mine.

${ }^{57}$ Ursula K. Heise, "Local Rock and Global Plastic: World Ecology and the Experience of Place," Comparative Literature Studies 41, no. 1 (2004): 147.

${ }^{58}$ Sy Taffel, "Technofossils of the Anthropocene Media, Geology, and Plastics," Cultural Politics 12, no. 3 (2016): 358.

${ }^{59}$ Yamashita, Through the Arc, 3. 
was "witnessed" by the narrator, cannot have gotten to us as readers without the intercession of other media. "Memory is a powerful thing," the narrator continues in the first paragraph, "although at the time I made my reentry into the world, no notice at all was taken of the fact." ${ }^{60}$ Like the memory of a computer - or, more precisely, like "an addition of 128k to [a computers] random access"- the narrator is a thing we depend upon completely for coherence and continuity, but whose "reentry" we don't necessarily have to pay material attention to. ${ }^{61}$ The question the narrator thus poses at the end of the novel is a kind of trick, since the memory of information technology - the memory of a digital archive - can't be said to belong to anybody at all, since media draws its power necessarily from the possibility of outside access: "Now the memory is complete," it states, "Whose memory you are asking? Whose indeed." The narrator is the memory of whoever has accessed it-it is a "communications satellite" in direct communication with a given reader.

Except, of course, it isn't: after dissolving into trash, eaten by bacteria, it reemerges "like any other dead spirit in the Afro-Brazilian syncretistic religious rite of Candomblé" and tells the story, we must imagine, from that position. Even if "media is constitutive of the religious imagination," as Martijs van de Port recently wrote of Brazilian Candomblé, and thus "scholars would do better to study religion as a practice of mediation," the transformation or reincarnation of the narrator from digital media into a religious or spiritual media remains something of a puzzle. ${ }^{62}$ Perhaps, I think Yamashita is suggesting, it would be best, faced with a medianature like that of Brazil, to expand our ideas about what media is to encompass both "useless objects" like a "statuette of Saint George" or "plastic roses," and the "dead spirit" of a religious ritual. ${ }^{63}$ The spirits of Candomblé, it might be said, are involved in the same cycle of nature-culture-waste-nature as the Matacão credit cards - both a ritual performed to invoke a spirit and a bit of plastic shaped to form a credit card both ultimately act as extensions of memory - and the narrator's transformation from plastic to spirit simply literalizes that relation. Indeed, explaining her frustration with the continued application of the term "magic realism" to her literary work, Yamashita says just that: in Brazil, where "international technology" proliferates freely, while "next door...people who have no relationship to that technology or use that technology in a manner that

\footnotetext{
60 Ibid.

${ }^{61}$ Ibid., 30.

${ }^{62}$ Mattijs van de Port, "Visualizing the Sacred: Video Technology, 'televisual' Style, and the Religious Imagination in Bahian Candomblé," American Ethnologist 33, no. 3 (2006): 445.

63 Yamashita, Through the Arc, 3.
} 
has nothing to do with it," the idea of "magic realism" falls apart as "magical thinking" is attached as readily to syncretic religious rites as it is to television and homing pigeons. ${ }^{64}$ Even J.B., the hyper-technological embodiment of the amalgam of media and humanity in the novel, can't help but imagine that his U.S. American corporate computer network ends with a link to the divine: "computer and electronics experts were interfacing office personnel to software programs," Yamashita writes, "software programs to terminals, terminals to VCRS, and VCRS to satellite computer systems, which J.B. imagined were probably interfaced with God." 65 As Shome makes clear, holistic theorization of medianatures in a postcolonial world cannot, as Yamashita underlines, remain tied to secular definitions of media if it wants to avoid the elision of media histories along established colonial lines. ${ }^{66}$ That the continuity of medianature extends from "office personnel" to notions of the divine-and that the linkages between them, from "wires" to "terminals," might be considered as emerging from and returning to a natural environment of hard materialismconstitutes Yamashita's most vital insight and her prescient contribution to the study of media, the environment, and their geopolitical context. ${ }^{67}$ The final image of the novel, of "crumbling remains of once modern high-rises and office buildings...trees arching through windows, a cloud of perpetual rain and mist and evasive color hovering over everything," signals not a simple "return" of nature, but the continuation of medianature, its connection to a deep past, and its continued conceptual relevance to an ecologically uncertain future. ${ }^{68}$

\footnotetext{
64 Yamashita, “Karen Tei Yamashita: An Interview," 1 Jan. 1994, 50.

65 Yamashita, Through the Arc, 56.

66 Shome, 254.

67 Yamashita, Through the Arc, 56.

${ }^{68}$ Ibid., 212.
} 


\section{Works Cited}

Barthes, Roland. "Plastic.” In Mythologies, 97-99. New York: Noonday Press, 1972.

Beck, Ulrich. Risk Society: Towards a New Modernity. Newbury Park, CA: Sage Publications, 1992 [1986].

Boes, Tobias, and Kate Marshall. "Writing the Anthropocene An Introduction." The Minnesota Review no. 83 (2014): 60-72.

DeLoughrey, Elizabeth M., and George B. Handley, eds. Postcolonial Ecologies: Literatures of the Environment. New York: Oxford University Press, 2011.

Elerding, Carolyn. "The Materiality of the Digital: Petro-Enlightenment and the Aesthetics of Invisibility." Postmodern Culture 26, no. 2 (2016).

Escobar, Arturo. "Nature." In Territories of Difference : Place, Movements, Life, Redes, 111-55. Durham, NC: Duke University Press, 2008.

Fanon, Frantz. The Wretched of the Earth. Translated by Constance Farrington. New York: Grove, 2002 [1961].

Fernandez, Maria. "Postcolonial Media Theory." Art Journal; New York 58, no. 3 (1999): 58-73.

Flusser, Vilém. Into the Universe of Technical Images. Minneapolis, MN: University of Minnesota Press, 2011 [1985].

Heise, Ursula K. "Local Rock and Global Plastic: World Ecology and the Experience of Place.” Comparative Literature Studies 41, no. 1 (2004): $126-52$.

—. "Unnatural Ecologies: The Metaphor of the Environment in Media Theory." Configurations 10, no. 1 (2003): 149-68.

Huber, Matt. Lifeblood : Oil, Freedom, and the Forces of Capital. Minneapolis, MN: University of Minnesota Press, 2013.

Larkin, Brian. Signal and Noise: Media, Infrastructure, and Urban Culture in Nigeria. Durham, NC: Duke University Press, 2008.

Masco, Joseph. "Mutant Ecologies: Radioactive Life in Post-Cold War New Mexico.” In Global Political Ecology, edited by Richard Peet, Paul 
Robbins, and Michael Watts, 285-303. London and New York: Routledge, 2011.

Maurer, Bill. "Does Money Matter? Abstraction and Substitution in Alternative Financial Forms.” In Materiality, edited by Daniel Miller, 140-64.

Durham, NC: Duke University Press, 2005.

Maxwell, Richard, and Toby Miller. Greening the Media. New York: Oxford University Press, 2012.

McHale, Brian. "Real, Compared to What?” In Postmodernist Fiction, 84-98. New York: Methuen, 1987.

McNeil, J.R. Mosquito Empires: Ecology and War in the Greater Caribbean, 1620-1914. Cambridge, UK: Cambridge University Press, 2010.

McLuhan, Marshall. Understanding Media: The Extensions of Man. New York: McGraw-Hill, 1964.

Merten, Kai, and Lucia Krämer, eds. Postcolonial Studies Meets Media Studies: A Critical Encounter. Bielefeld: Transcript, 2016.

Parikka, Jussi. A Geology of Media. Minneapolis, MN: University of Minnesota Press, 2015.

—. "Electronic Waste/Introduction." Medianatures: The Materiality of Information Technology and Electronic Waste. Open Humanities Press, 2011. 18 Apr. 2017. Living Books About Life. http://www.livingbooksaboutlife.org/books/Electronic_waste/Introducti on.

Peters, John Durham. The Marvelous Clouds: Toward A Philosophy Of Elemental Media. Chicago: University of Chicago Press, 2015.

Shome, Raka. "When Postcolonial Studies Meets Media Studies." Critical Studies in Media Communication 33, no. 3 (2016): 245-63.

Taffel, Sy. "Technofossils of the Anthropocene Media, Geology, and Plastics." Cultural Politics 12, no. 3 (2016): 355-75.

Van De Port, Mattijs. "Visualizing the Sacred: Video Technology, 'televisual' Style, and the Religious Imagination in Bahian Candomblé." American Ethnologist 33, no. 3 (2006): 444-61.

Wallace, Molly. "'A Bizarre Ecology' The Nature of Denatured Nature.” ISLE: Interdisciplinary Studies in Literature and Environment 7, no. 2 (2000): 137-53. 
Wolfe, Cary. "Introduction: What Is Posthumanism." What Is Posthumanism? xi-xxxiv. Minneapolis, MN: University of Minnesota Press, 2010.

Yamashita, Karen Tei. "Karen Tei Yamashita: An Interview.” 1 January 1994.

- Through the Arc of the Rain Forest : A Novel. Saint Paul, MN: Coffee House Press, 1990.

—. "Twenty Years After Through the Arc of the Rain Forest: An Interview with Karen Tei Yamashita." 7 May 2010.

Yoshida, Shosuke et al. "A Bacterium That Degrades and Assimilates Poly(ethylene Terephthalate).” Science 351.6278 (2016): 1196-99. 